Article

\title{
Fast Fashion Avoidance Beliefs and Anti-Consumption Behaviors: The Cases of Korea and Spain
}

\author{
Namhee Yoon ${ }^{1}$, Ha Kyung Lee ${ }^{2, * \mathbb{C}}$ and Ho Jung Choo ${ }^{2,3}$ \\ 1 Department of Home Economics Education, Korea University, Seoul 02841, Korea; v7nami@gmail.com \\ 2 Department of Textiles, Merchandising, and Fashion Design, Seoul National University, Seoul 08826, Korea; \\ chooho@snu.ac.kr \\ 3 Research Institute of Human Ecology, Seoul National University, Seoul 08826, Korea \\ * Correspondence: agape@snu.ac.kr; Tel.: +82-2880-8769
}

Received: 29 June 2020; Accepted: 22 August 2020; Published: 25 August 2020

\begin{abstract}
The ethics of the fast fashion industry have been called into question with the emergence of new consumption paradigms, such as anti-consumerism and sustainable consumption. This study aims to explore the conceptual structure of fast fashion avoidance beliefs that have led to the anti-consumption of fast fashion. Data were collected from female consumers aged between 20 and 39 years with experiences of purchasing fast fashion brands in Korea and Spain. The structure of avoidance beliefs was compared through second-order factor analysis, and the data were analyzed using multiple regression. The structure of avoidance beliefs showed satisfactory validity and reliability in Korea, whereas deindividuation and foreignness were not included as negative beliefs in Spain. An analysis of the association between negative beliefs and anti-consumption showed that deindividuation and foreignness had positive effects on the anti-consumption of fast fashion in Korea. In Spain, poor performance and irresponsibility had positive effects, while overly trendy style had a negative effect on the anti-consumption of fast fashion. These findings contribute to the literature on anti-fast fashion consumption as part of the ethical apparel consumption movements. We can understand global consumers' anti-consumption of fast fashion, diagnose the current status of fast fashion in the global market, and even suggest future directions for fast fashion retailers.
\end{abstract}

Keywords: fast fashion; fast fashion avoidance; avoidance belief; anti-consumption of fast fashion; Korea; Spain

\section{Introduction}

The term "fast fashion" refers to low-price clothes that move from the catwalk to a mass market by replicating current luxury fashion trends [1]. Fast fashion is characterized by a short lead-time, mass production, and quick inventory turnarounds, with up-to-date merchandise produced bi-weekly [2-4]. It also enables consumers to obtain satisfaction with affordable and on-trend clothing pieces that replicate their fashionable counterparts at low prices, thereby fostering hyper-consumption [1, 4]. Despite the advantages for consumers, fast fashion has been criticized for its contribution to social and environmental hazards, such as poor working conditions in developing countries, intellectual property concerns, toxic chemical pollution, and carbon dioxide emission [1,5-7]. Fast fashion, which is supposed to present new styles in a store every week with cheap prices, also embodies a fast-response system that encourages disposability [5]. Fast fashion enables consumers to purchase new styles easily and dispose outdated clothes at a rapid rate [8,9]. The Rana Plaza incident in 2013 has had a critical effect on the way many consumers perceive the fast fashion industry. The tragic deaths of 1136 sewing 
workers were known to global consumers, and have resulted in greater awareness of inhumane labor conditions and unethical firm practices $[10,11]$. This incident gave rise to the global fashion revolution movement that promotes an anti-fashion agenda through the fashion revolution week [12].

Such increasing awareness of the societal and environmental potential effects of the fast fashion industry has led consumers to "vote" with their purchase by making more informed purchasing decisions and avoiding products manufactured or distributed by an unethically perceived company [13,14]. An industry-wide movement toward ethical practice and legitimizing the role of unethical fast fashion has been occurring in the fashion marketplace [15]. Besides, given the emergence of new consumption paradigms, such as anti-consumerism, eco-friendliness, and ethical consumption, some consumers have become disillusioned with thoughtless consumption and its side effects on society [7]. The terms "anti-consumerism", "sustainable consumption", and "ethical consumption" are often used to describe consumers' behaviors associated with consumer resistance, boycotting, anti-cultural movements, and non-consumption [16].

As a result, many fast fashion retailers have been exerting efforts to attract consumer attention with sustainable strategies in terms of production, distribution, supply stages, and marketing. For instance, C\&A, fast retailing, Inditex, and other apparel companies have joined the Accord and the Alliance for Bangladesh Worker Safety [17] in response to media and consumer sentiments towards fair labor wages and conditions, contributing to charities and protecting the environment [14]. Specifically, in 2018, "Uniqlo" announced a new environmental policy that includes five areas for sustainable action: climate change, energy efficiency, water stewardship, waste management and resource efficiency, and chemical management [18]. H\&M has already started its sustainable action through the Conscious Collection, which uses organic materials. Moreover, H\&M also announced plans to replace all its materials and products with renewable or sustainable materials by 2030 through its Conscious Collection [19]. However, is this series of attempts by fast fashion retailers enough to change consumers' minds? The question remains open, and few studies have explored it [20]; thus, we have limited information to diagnose the effectiveness of sustainable strategies by fast fashion retailers from a consumer perspective. The majority of previous studies on anti-fast fashion have focused on consumers' attitudes and behaviors toward sustainability rather than on anti-consumption itself; even recent studies have also focused on these areas. For example, Blazquez et al. [4] examined consumer intentions toward sustainable fashion in the Spanish fashion industry, while Blasi et al. [21] explored the correlation between eco-friendliness and fashion brands' perceptual attribute (e.g., luxury, high, and fast fashion brands) using Twitter data. Stringer et al. [20] investigated the effect of consumer values and ethical concern within the fast fashion industry on purchase intentions toward fast fashion. Noh and Mortimer [22] revealed apparel brands' sustainability efforts on consumers' brand loyalty with three different brand types, including fast fashion brands. Besides this, several studies have focused on consumer behavior, which highlights the gap between perceptions, attitudes, and behaviors toward fast fashion brands $[4,23,24]$. Many revious studies that have dealt with the sustainability concern in the textile and apparel industry were linked with fast fashion issues because a fast fashion brand is regarded as the main player in fostering the footprint of fashion industry in terms of the overconsumption of products. However, limited studies have explored consumers' anti-fast fashion behaviors. Consumers' anti-fast fashion or fast fashion avoidance behaviors are different concepts that should be distinct from either a low preference for fast fashion or a high preference for slow fashion [25]. That is, knowing what consumers do not want is just as valuable as knowing what they want. Although fast fashion brands still make a profit and ranked high in terms of worldwide revenue in 2019 [26], a new movement that challenges the fast fashion paradigm has emerged. In this regard, we need to explore why people are reluctant to purchase and consume fast fashion to understand the current status and suggest prospects for the fast fashion industry in the future. The purpose of the current study is to explore global consumers' anti-fast fashion consumption. Specifically, the objectives of this study are twofold. First, this study attempts to reconfirm the conceptual structure of fast fashion avoidance beliefs in Korea and Spain by using the conceptual structure proposed by Kim et al. [25]. 
Second, this study tests empirically the effects of fast fashion avoidance beliefs on anti-fast fashion consumption in both countries. The choice of the two countries is appropriate in reconfirming and generalizing the conceptual structure of fast fashion avoidance beliefs because they have similar economic status in terms of their gross domestic product (GDP) and purchasing power parity (PPP). They are also similar in terms of sales volume and fashion industry value $[27,28]$. However, they also have distinctively different cultures as Asian and Western countries. Korea has a collectivist-oriented culture, while Spain has a Catholic-influenced individualism culture [29]. In addition, the role of fast fashion retailers may differ in the two countries. Spain is an origin country where fast fashion brands such as ZARA and MANGO were first launched, and fast fashion retailers in Spain are common and easily seen everywhere. However, fast fashion retailers in Korea are imported from abroad, mainly Spain, and well established in the country. Thus, Korean consumers may have less accumulated experience or knowledge regarding fast fashion compared to Spanish consumers. In this regard, we raise two research aims: (1) to examine the conceptual structure of fast fashion avoidance beliefs in Korea and Spain and (2) to identify the effects of negative beliefs on the anti-consumption behavioral intention for fast fashion in Korea and Spain. Young consumers in particular exhibited the paradox of sustainable fashion [30], in which consumers favor fast fashion (i.e., the anti-sustainable brand) and sustainable consumption simultaneously. Thus, this study also can help to address this sustainable fashion paradox by identifying why young consumers in Korea and Spain avoid fast fashion.

The current study contributes to the literature on anti-fast fashion consumption as a part of sustainable and ethical apparel consumption movements. Although traditional consumer research on sustainability has been associated mainly with social and environmental concerns, interest in anti-consumption is expanding, as seen in the current trends in the global fast fashion market. Comprehending why consumers do not consume fast fashion is necessary in order to gain a clearer picture of consumers' ethical and sustainable apparel consumption behavior. Through the results, we can understand global consumers' anti-consumption of fast fashion, diagnose the current status of fast fashion in the global market, and suggest future directions for fast fashion retailers.

\section{Literature Review}

\subsection{Fast Fashion}

Over the past decade, the fast fashion phenomenon has revolutionized the textile and apparel industry. "Fast fashion" is a term used by fashion retailers to express the designs and styles that capture current fashion trends [31]. Fast fashion refers to designs that reflect the quick response to up-to-date trend or styles moving swiftly from runway to stores to increase the product value and demand for short-cycle fashion products [32,33]. Fast fashion retailers aim to shorten the lead time in supply chain management (SCM) and pursue rapid responsiveness to the diverse needs of consumers [34]. The standard lead time from the catwalk to consumers is approximately six months in the conventional system. In comparison, fast fashion retailers such as ZARA, H\&M, MANGO, and Topshop, thrive on a fast cycle and introduce new products weekly to attract fashion consumers.

Fashion brands compete not only on price but also on their ability to deliver a "refresh" product [35]. From the perspective of consumers, fast fashion is often characterized by the simultaneous presentation of runway styles and affordable pricing. Cachon and Swinney [36] indicate that fast fashion retailers have distinct value in terms not only of quick response capability as a production system but also of enhanced design offerings. These strategies of fast fashion (i.e., enhanced design and quick response) achieve mass-market gratification by delivering products with style at an affordable price immediately.

The advantages of fast fashion (e.g., up-to-date styles, affordable price, quick response to consumers' demand, etc.) has allowed the industry to expand into international markets to incorporate new technologies and the supply chain and to search for new suppliers and new consumers' scope [37]. Martinez-Barreiro [38] indicated that the pioneer of this internalization was "Benetton", which had the six-month lead-time of their products outsourced. Then, the next group of internationalized 
fashion companies such as "GAP" reduced the product cycle to two months. The "ZARA" brand, which belonged to the Inditex group, was able to reduce the lead-time to up to two weeks, making it one of the most successful fashion retailers on the globe. ZARA was launched in 1975 and entered a new market abroad in 1988. Childs and Jin [39] found that fast fashion retailers, such as ZARA and H\&M, rapidly internationalized their business in the 2000s, expanding specifically to the Asian countries.

However, despite its rapid growth in the global market, the fast fashion industry is still confronted with social, ethical, and environmental problems from the production to inventory process. Several media outlets have reported on ethical issues, such as poor working conditions and the exploitation of child labor, as well as environmental issues such as tons of apparel waste due to overconsumption and increased emissions of toxic chemicals due to fast fashion [40]. With these issues, consumers are becoming increasingly aware of the status of sustainability in the fast fashion industry.

\subsection{Challenge to Fast Fashion}

\subsubsection{Dark Sides of Fast Fashion}

Previous research has questioned the ethics of the fast fashion industry $[8,41]$. The general premise of fast fashion is that new styles with cheap prices should be offered in stores every week, which can be achieved by employing workers in underdeveloped nations, using cheap hazardous materials, and copying a pre-made design [42]. The overconsumption of fast fashion has had adverse effects on the earth's natural resources and also raises social and ethical problems, giving rise to the emergence of the anti-consumption of fast fashion. For example, last year, the "school global strike" involved more than one hundred nations and millions of young students around the world. In Portugal, over 20,000 students in 51 cities protested against the current status of the country's environmental policies; "There is no planet B" or "Our future is on your hands" were some slogans supported by Generation Z [23]. In other words, consumers resist, reject, or reduce their consumption of the goods and services of fast fashion $[23,43]$ because of social, environmental, and ethical issues.

Fast fashion retailers depend on low-wage workers in underdeveloped countries to keep costs down, make clothes in less time, and meet the lead time. These employees are not only not paid adequate living wages, but also labor under poor working conditions, are exposed to hazardous chemicals and the health risks associated with repetitive motion tasks, and even suffer abuse from managers [44,45]. Even though most of these workers are not employed directly by fast fashion retailers, these global companies are not free from increasing criticism of the ethical and social problems associated with sweatshops in developing countries.

The fast fashion industry consumes a tremendous amount of textile material from natural and chemical sources and utilizes various processing methods in manufacturing their final products. Cost-sensitive manufacturing often leads to environmental hazards. Approximately $90 \%$ of clothes manufactured by fast fashion retailers are made with cotton or polyester, both associated with environmental harm to the ecosystem due to releasing toxic chemical pollution and emitting carbon dioxide during processing $[42,44,46]$. Textile dyeing is a crucial cause of water pollution because contaminated water carrying toxicants from the dyeing process can flow into the local water system, thereby affecting the health of living things [46,47]. Even though the harmful effects of textile production on ecosystems occur frequently in the global textile supply chain, fast fashion is the main culprit because of the nature of mass-production and mass-consumption.

Adding to the environmental impact of fast fashion are intellectual property concerns. Fast fashion relies on imitating haute couture and copying ready-to-wear designs from around the world to keep up with trends and fashionable styles on a daily basis [34,48-50]. Such copying enables fast fashion retailers to reduce the time of the creative process and meet the lead-time from design planning to the distribution of merchandise within a few weeks. In addition to replicating luxury brands, some fast fashion retailers also copy other fast fashion retailers to sell products at even lower prices [42]. Such instantaneous copying of designs in other fashion retailers causes another problem in consumers' 
circular use of apparel. Consumers are not only purchasing new styles but disposing of outdated fashion at a rapid rate [8,9]. In this regard, fast fashion is occasionally called "McFashion" [51], which means fast and convenient fashion, similar to McDonald's, or "disposable fashion" that is used and simply thrown away.

\subsubsection{Consumer Ethics and Sustainability in Fast Fashion}

Consumers nowadays are interested in social and environmental concerns, and this tendency to be "ethical" and "sustainable" has come to the forefront in terms of consumers' buying patterns. Over the past decade, "ethical" and "sustainable" issues have become important in the fashion industry [52]. As an attempt to create a sustainable initiative in the fashion industry, the "Garment Worker Diaries" project began in 2016 to improve the transparency of global supply chains. The Microfinance Opportunities (MFO), in collaboration with local research firms in Bangladesh, India, and Cambodia, collected data related to women's working status in each country weekly for a year. The "Fashion Transparency Index" reported from the Fashion Revolution showed annually how much the world's largest fashion brands and retailers disclose their social and environmental policies, practices, and impacts. These kinds of projects encourage fashion brands to account for the human rights and environmental impacts of their practices. Many previous studies have highlighted the increasing emphasis on ethics and sustainability in fashion consumption. Pookulangara and Shephard [53] reported that people believe the slow fashion movement is an ideal situation with which to proceed for the future. The slow fashion movement focuses on sustainability, fair labor conditions, and high-quality timeless clothing [14,54], and the direction appears to be the opposite of fast fashion. Fletcher [5] argued that the high-quality/high-pricing strategy of slow fashion would make consumers perceive more value for the brands and products, encouraging them to keep the item longer rather than discarding them shortly after purchase. Jägel et al. [55] explored the motivation driving sustainable or ethical fashion consumption. The participants reported a relatively high incidence of ethical values, such as social justice, equality, and supporting the environment. Gam [56] revealed that consumers' fashion orientation, shopping orientation, environmental concerns, and eco-friendly behaviors are factors that increase purchase intentions toward environmentally friendly clothing. Diddi and Yan [57] explored consumers' specific barriers and motivations to engage in clothing repair and their likelihood to participate in clothes and community mending events as a specific sustainable behavior. Moreover, a growing number of studies have argued that consumers are interested in environmentally and ethically conscious consumption $[5,53,55,56]$ and are often willing to pay more for "green" products or "sweat-free" goods [58,59].

In terms of research exploring the sustainability issue associated with fast fashion, Blasi et al. [21] conducted a social network analysis and found that eco-friendly perception influenced brand image positively, with this effect being much higher for luxury than for fast fashion brands. This difference between luxury and fast fashion brands indicates that the recent tendency of fashion luxury brands is to consider treating environmental issues as part of their core business, which is the opposite for fast fashion brands. Stringer et al. [20] found that consumers' level of concern toward the environment and animal welfare had a positive effect on purchase intentions toward fast fashion brands that were ethically marked. Kim and Oh [40] quantitatively tested the associations of the keyword "eco-friendly fabric" and found that it had the most significant influence on building a sustainable brand image for fast fashion. These findings from previous research indicate that people are likely to aim for "responsible consumerism", reflecting a shift in the overall consumption consciousness and consumption patterns to a sustainable one $[40,60]$. More critically, young consumers, particularly Gen-Y consumers, show higher interests in the sustainability issues in the fast fashion industry. Even though young consumers are the main target customers for fast fashion brands, their preference for fast fashion is changing because of environmental problems (e.g., pollution and waste caused by manufacturing and production), human rights issues in developing countries where the clothing items are manufactured, and the copying of popular luxury brand designs. According to Marques et al.'s paper [23], the $Z$ and M 
generations in Europe (e.g., Portugal, Germany, Spain, etc.) mounted protests against politicians, businessmen, and consumers to declare a "climate emergency". In particular, this action has been directed towards the clothing and textiles industries, which are considered key players (e.g., fast fashion brands) in increasing pollution and the carbon footprint. This situation where young consumers favor both fast fashion and sustainable consumption simultaneously can be called the paradox of sustainable fashion [30]. In the light of the many studies on consumers' environmental and sustainable concerns about fashion consumption, the lack of theoretical and conceptual works in the field and the scarce amount of empirical evidence on their anti-fashion consumption need to be addressed.

\subsection{Fast Fashion Avoidance}

\subsubsection{Brand Avoidance}

"Brand avoidance" refers to incidents in which people purposely choose to reject a brand [61], or dissatisfaction leading to brand avoidance and switching [62]. In the study on dissatisfaction conducted by Oliva et al. [62], the term brand avoidance was used as the anti-thesis of brand loyalty, and was considered similar to brand switching. Oliva et al. [62] proposed that consumers' dissatisfaction leads to brand avoidance or brand switching; however, brand switching is a pattern of behavior associated with the change from one brand to another, while brand avoidance focuses specifically on brand rejection [61]. The majority of previous research on brand avoidance has explored the factors motivating it. Thompson et al. [63] explored consumers' anti-Starbucks behavior and determined that inauthentic brand meanings motivate consumers to avoid the Starbucks brand. Rindell et al. [64] indicated that consumers that place strong value on consumption (e.g., ethical value) are likely to reject brands in terms of brands' persistency and explicitness.

Brand avoidance has been observed from the context of anti-consumption [65], indicating more stable and long-term reasons for rejection. Lee et al. [61] also use the term anti-consumption with brand avoidance interchangeably. Similar to brand avoidance, anti-consumption is associated with a reduction in general consumption [66] or the consumption of specific brands or products [67]. Anti-consumption also includes consumer behaviors of decreased consumption by reusing and recycling products. Although the majority of consumer studies have focused on the positive consumption of brands, interest in anti-consumption is increasing. Hence, understanding why consumers prefer not to consume a specific brand is important.

Previous research on brand avoidance has mainly focused on unidimensional factors driving brand avoidance [62-64]. However, Lee et al. [61] explored the motivation for the anti-consumption of certain brands and revealed three types of brand avoidance-namely, experiential, identity, and moral brand avoidance. Consumers are likely to show experiential brand avoidance because of the gap between their expectations and brand performance (i.e., unmet expectations) in terms of poor performance, inconvenience, and unpleasant store environments. Consumers exhibit identity brand avoidance when they face incongruence between brands' symbolic meaning and individual's self-identity (i.e., symbolic meaning). Finally, moral brand avoidance is motivated by ideological incompatibility based on consumers' political and socio-economic beliefs. Lee et al. [68] also added deficit-value avoidance to the three types of brand avoidance and identified four types of reasons for brand avoidance-namely, experiential, identity, moral, and deficit-value avoidance. Deficit-value avoidance occurs when a brand is perceived to have an unacceptable price compared to its benefit. Consumers might avoid brands perceived as low-quality and that consequently are deficient in value [68]. Furthermore, Knittel et al. [69] fount that an additional type of brand avoidance - that is, advertising avoidance among Generation Y. Advertising, including content, a celebrity endorser, music, and the response to the advertisement can generally influence consumers' decision-making on what they do or do not buy [69]. 


\subsubsection{Fast Fashion Avoidance Belief}

Kim et al. [25] used the brand avoidance model suggested by Lee et al. [61] as a basis to investigate the conceptual structure of fast fashion avoidance, with particular focus on the negative beliefs of fast fashion. The authors first suggested eight types of negative beliefs surrounding fast fashion (i.e., poor performance, overly trendy style, big store discomfort, lack of personal help, inauthenticity, deindividuation, irresponsibility, and foreignness) from the analysis of blog contents [25]. The structure of negative beliefs was confirmed through a confirmatory factor analysis (CFA) with the data in a web-based online survey. Accordingly, they presented second-order factors with "unmet expectations", "symbolic incongruence", and "ideological incompatibility".

Unmet expectations are reflected in four types of negative beliefs, including those related to poor performance, overly trendy style, big store discomfort, and the lack of personal help. Poor performance refers to the low product quality of fast fashion (e.g., stitching, materials, and durability). The overly trendy style indicates whether fast fashion styles are considered trendy and sensitive to changing trends. Big store discomfort refers to the inconvenience caused by the size of a store (e.g., too big to browse the merchandise in the store, thus making the customers feel discomfort), while the lack of personal help pertains to a salesperson's service in a store.

The second construct, symbolic incongruence, is reflected in inauthenticity and deindividuation. Inauthenticity is related to the replication of the designs of famous brands, including imitating haute couture and copying ready-to-wear designs from around the world. It also describes fast fashion styles as being not original and having excessive mass appeal. Deindividuation is associated with the expression of personality through fast fashion. For example, if people think that clothes in fast fashion are all the same pieces and have no creativity and because everyone shops at the same place, they may have a negative belief associated with deindividuation.

Additionally, irresponsibility and foreignness are confirmed as representing the final construct-namely, ideological incompatibility. Irresponsibility is the concept related to sustainability, including environmental concerns and labor issues (e.g., unfair labor, child labor, dangerous work environments). Foreignness represents the psychological dissension and cultural distance caused by individual identity damage under cultural pressure during fast fashion consumption. Cavender and Lee [70] explored the fashion leaders' motivations and attitudes toward slow versus fast fashion. The findings showed that sustainability awareness had a positive effect on the orientation to slow fashion consumption but did not have any significant effect on the drivers of fast fashion avoidance. The result also revealed that consumers' orientation to consume slow fashion had a positive influence on several fast fashion avoidance drivers, including deindividuation and irresponsibility. Kim et al. [25] also identified the effects of the eight negative beliefs on the behavioral intentions of fast fashion avoidance. The results of a multiple regression analysis showed that poor performance, deindividuation, and foreignness increased consumers' behavioral intention to avoid fast fashion brand consumption. However, inauthenticity had a negative effect on behavioral intention. In particular, deindividuation was the most critical factor driving fast fashion avoidance, followed by foreignness, inauthenticity, and poor performance. The interesting results of this previous study could help fast fashion brands to understand what consumers want and why they choose to avoid fast fashion.

\section{Methodology}

\subsection{Research Questions}

In the past decades, fast fashion has emerged as a global trend, causing consumers to purchase multiple clothes at once and discard them easily, which has resulted in the shortening of the lifecycle of apparel consumption and increasing fashion waste. Meanwhile, the movement on environmental and social welfare caused by non-ethical fast fashion practices has also been growing, placing into question the future of fast fashion and its direction. Hence, to identify the direction and prospects of fast fashion, this study seeks to identify consumers' negative beliefs that drive fast fashion avoidance in Korea and Spain. The specific research aims are constructed as follows: 
- RQ1. We will examine the conceptual structure of fast fashion avoidance beliefs in Korea and Spain.

- RQ2. We will identify the effects of negative beliefs on the anti-consumption behavioral intention towards fast fashion in Korea and Spain.

\subsection{Measurement}

The measurements of fast fashion avoidance beliefs were based on Kim et al. [25]. Kim et al. [25] identified eight fast fashion avoidance beliefs under three dimensions: (1) the "unmet expectation" dimension, which includes poor performance, overly trendy styles, and big store discomfort; (2) the "symbolic incongruence" dimension, which includes deindividuation and inauthenticity; and (3) the "ideological incompatibility" dimension, which includes irresponsibility and foreignness. Fast fashion avoidance beliefs were measured using 26 items for the eight sub-dimensions. Anti-fast fashion consumption was defined as avoidance behavioral intention towards fast fashion and was measured using three items. These items were originated by Kim et al. [25]. The three items measure the level of agreement of consumers to the statements describing negative behavioral intention to visit stores, shop, and recommend to others.

The measurement scales for the Korean study were translated into Spanish. The Spanish scales were retranslated to Korean and compared with the original scale to ensure the validity and reliability of the translated scales. The measurements were then confirmed by modifying the words used.

Demographics and fashion involvement were measured to compare the characteristics of consumers in Korea and Spain. The measurement scale for fashion involvement included interest in clothing and a tendency to consider clothes (Cronbach's $\alpha=0.833$ ). A five-point Likert scale was used to measure the multi-item scales.

\subsection{Data Collection}

\subsubsection{Spain and Korea}

Surveys were conducted in the capital cities of Seoul and Madrid to compare the fast fashion avoidance between Korea and Spain, respectively. As of 2019, Spain has an estimated population of 46.74 million, which is similar to Korea's population of 51.34 million. The economic statuses of the two countries are likewise relatively similar. The 2018 gross domestic product (GDP) in Korea is $\$ 1,619,424$ million, and it is $\$ 1,425,865$ million in Spain. The two countries are also similar in the sales volume and value of the fashion industry. Data from Statista indicate that the fashion market in Korea (excluding footwear and jewelry) was worth \$24,252 million in 2017 and ranked 11th in the world in the value of the apparel retail market. Similarly, the apparel retail market in Spain was worth $\$ 21,402$ million in 2017 (12th in the world).

Although the fashion market sizes of Korea and Spain appear similar to each other, the fast fashion market in these countries followed a different pattern. Korean consumers first experienced global fast fashion brands in their domestic market in the early 2000s. The global fast fashion brands had high annual growth rates at the early stage after entering the Korean market [71]. Given the early success of global fast fashion brands in the Korean market, Korean fashion companies launched domestic fast fashion brands, where the market size of the top 3 fast fashion brands (e.g., ZARA, H\&M, and UNIQLO) was worth $\$ 1653$ million in 2018, based on the annual report of each brand.

Spain is the home of many global fast fashion brands, such as ZARA and MANGO. The top 15 retailers in Spain are fast fashion brands, with ZARA taking the first spot, followed by Primark and H\&M. In this regard, fast fashion in Spain has matured over time and has become the mainstream in the fashion market since 1975. Therefore, fast fashion has become inherent in consumers' life beyond simply popular fashion trends. By contrast, Korean consumers are likely to consider fast fashion as one of the popular fashion trends that will pass. 


\subsubsection{Samples}

The subjects were consumers who had experiences shopping in fast fashion. In the study, fast fashion was defined as well-known brands such as ZARA, MANGO, H\&M, Topshop, and Forever21, which are representatives of current fast fashion trends for young females in Korea and Spain. These fast fashion retailers provide designs and styles to capture current fashion trends [1,31], and their target consumers consist mainly of young females. Young consumers have a favorable attitude toward fast fashion and sustainable consumption simultaneously [30]. Thus, we can explain the sustainable fashion paradox by identifying why young consumers in Korea and Spain avoid fast fashion.

Following Kim et al. [25], the study collected data from female consumers with ages between 20 and 39 years who had at least one experience of purchasing from fast fashion retailers. Data were collected through convenience sampling in both countries. In Spain, the survey was conducted in person, and in Korea it was conducted through an online survey using research panel data from July to August 2016. Four unreliable responses from the data collected in Spain were excluded from the analysis. A total of 427 complete responses were collected (i.e., 224 and 203 samples in Korea and Spain, respectively). In terms of age, $63.2 \%$ of the Korean sample were in their 20 s and $36.8 \%$ were in their 30s. In Spain, $70.4 \%$ of the samples were in their 20 s and $29.6 \%$ were in their 30 s.

Income, fashion expenditure, and fashion involvement were compared to confirm the similarities in consumption among the samples in the two countries. No significant difference was observed in the average monthly income of households in Korea and Spain (Table 1). Although the average expenditure on fashion products is higher in Korea than in Spain (mean in Korea $=\$ 13$, mean in Spain $=\$ 10, t=5.184, p=0.000)$, no significant difference was observed in the fashion involvement of the two countries (mean in Korea $=4.969$, mean in Spain $=4.751, t=1.829, p=0.068$ ). Thus, the samples of the two countries are confirmed to be similar in terms of fashion consumption, and thus the study was conducted based on the samples.

Table 1. Samples.

\begin{tabular}{cccc}
\hline & Korea $(\boldsymbol{n}=\mathbf{2 2 4})$ & Spain $(\boldsymbol{n}=\mathbf{2 0 3})$ & $\boldsymbol{t}$-Value \\
\hline Monthly income of households & $\$ 3900$ & $\$ 3580$ & 1.857 \\
Fashion expenditure & $\$ 13$ & $\$ 10$ & $5.184^{* * *}$ \\
Fashion involvement & 4.969 & 4.751 & 1.829 \\
\hline & $* * * p<0.001$. &
\end{tabular}

\section{Results}

\subsection{Structure of Fast Fashion Avoidance Beliefs: Korea vs. Spain}

First, the structure of beliefs on fast fashion avoidance was analyzed to test if the proposed model fits data through a second-order confirmatory factor analysis (CFA) using AMOS 23.0 (IBM, Armonk, NY, USA).

In Korea, the construct structure was found to fit the data. Figure 1 shows that fast fashion avoidance beliefs, such as poor performance, overly trendy style, big store discomfort, and the lack of personal help, were specified to reflect unmet expectations. Meanwhile, inauthenticity and deindividuation were confirmed to represent the higher construct of symbolic incongruence, and ideological incompatibility was reflected in irresponsibility and foreignness $\left(\chi^{2}=275.128, d f=141\right.$, $p=0.000$, normed $\chi^{2}=1.951$, goodness of fit index $(\mathrm{GFI})=0.883$, comparative fit index $(\mathrm{CFI})=0.937$, root mean square error of approximation $($ RMSEA $)=0.065)$. 


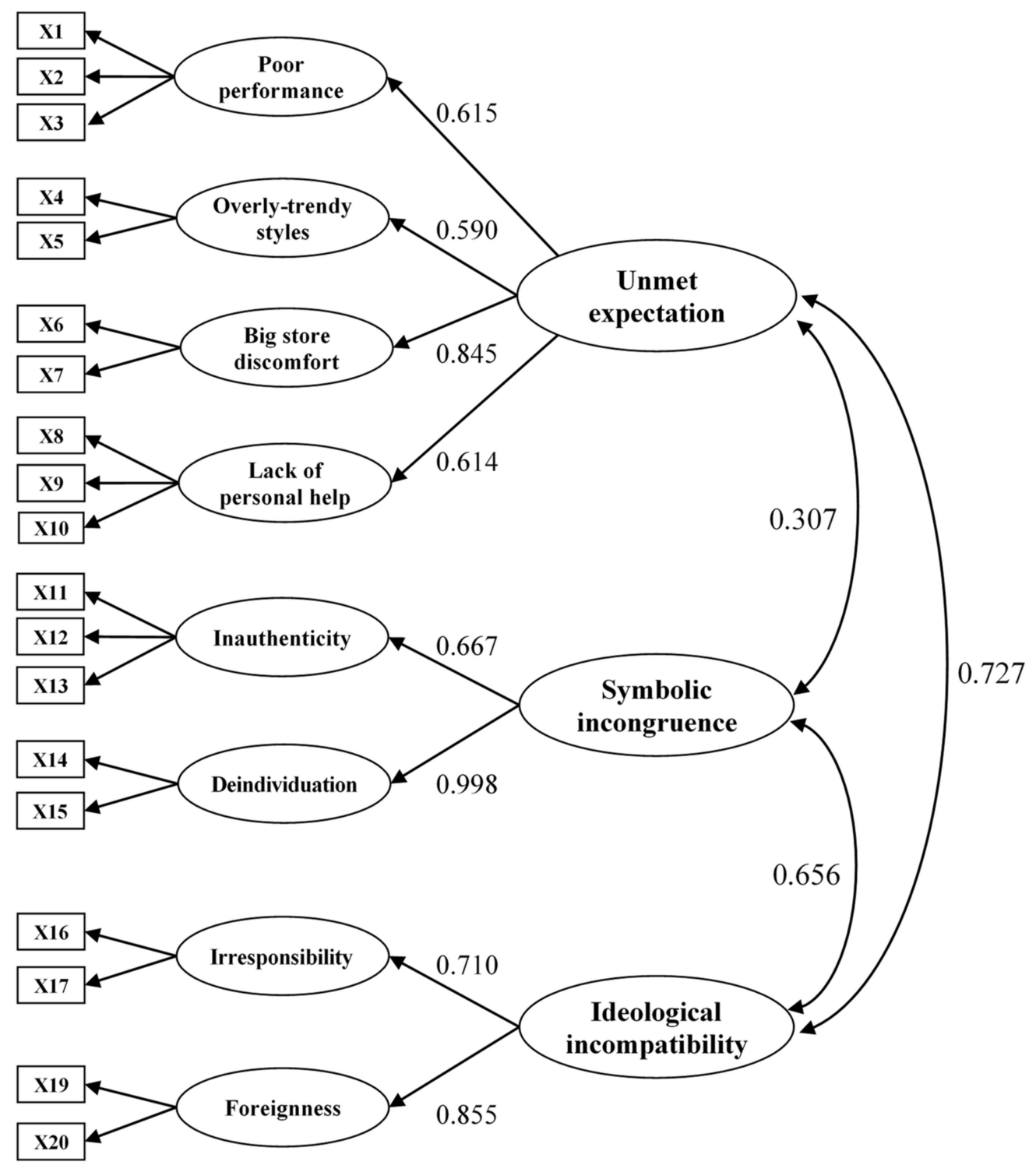

Figure 1. Korea: second-order confirmatory factor analysis. Notes: $\chi^{2}=275.128(d f=141, p=0.000)$, normed $\chi^{2}=1.951, \mathrm{GFI}=0.883, \mathrm{CFI}=0.937$, RMSEA $=0.065$. All the estimates are statistically significant at $p<0.01$.

In Spain, unmet expectations were reflected in poor performance, big store discomfort, and the lack of help. The higher-order construct of symbolic style, which consisted of overly trendy style, inauthenticity, and irresponsibility, was confirmed as a higher-order construct (Figure 2). Deindividuation and foreignness were not included in the avoidance beliefs in fast fashion in Spain. Consumers in Spain are not likely to perceive foreignness and deindividuation as negative beliefs of fast fashion, which is understandable considering the long history and birth of fast fashion brands in Spain.

A competing model was specified, and a second-order CFA was conducted to confirm the superiority of the proposed model structure (Figure 3). For the competing model (Figure 4), the overly trendy style was specified to reflect unmet expectations, and inauthenticity was independently constructed as a higher-order factor. A comparison of the $\chi^{2}$ differences (Table 2) showed that the fit index of the proposed model is superior to that of the competing model. Hence, no significant difference exists between the two models $\left(\Delta \chi^{2} / d f=22.527, p<0.001\right)$. 


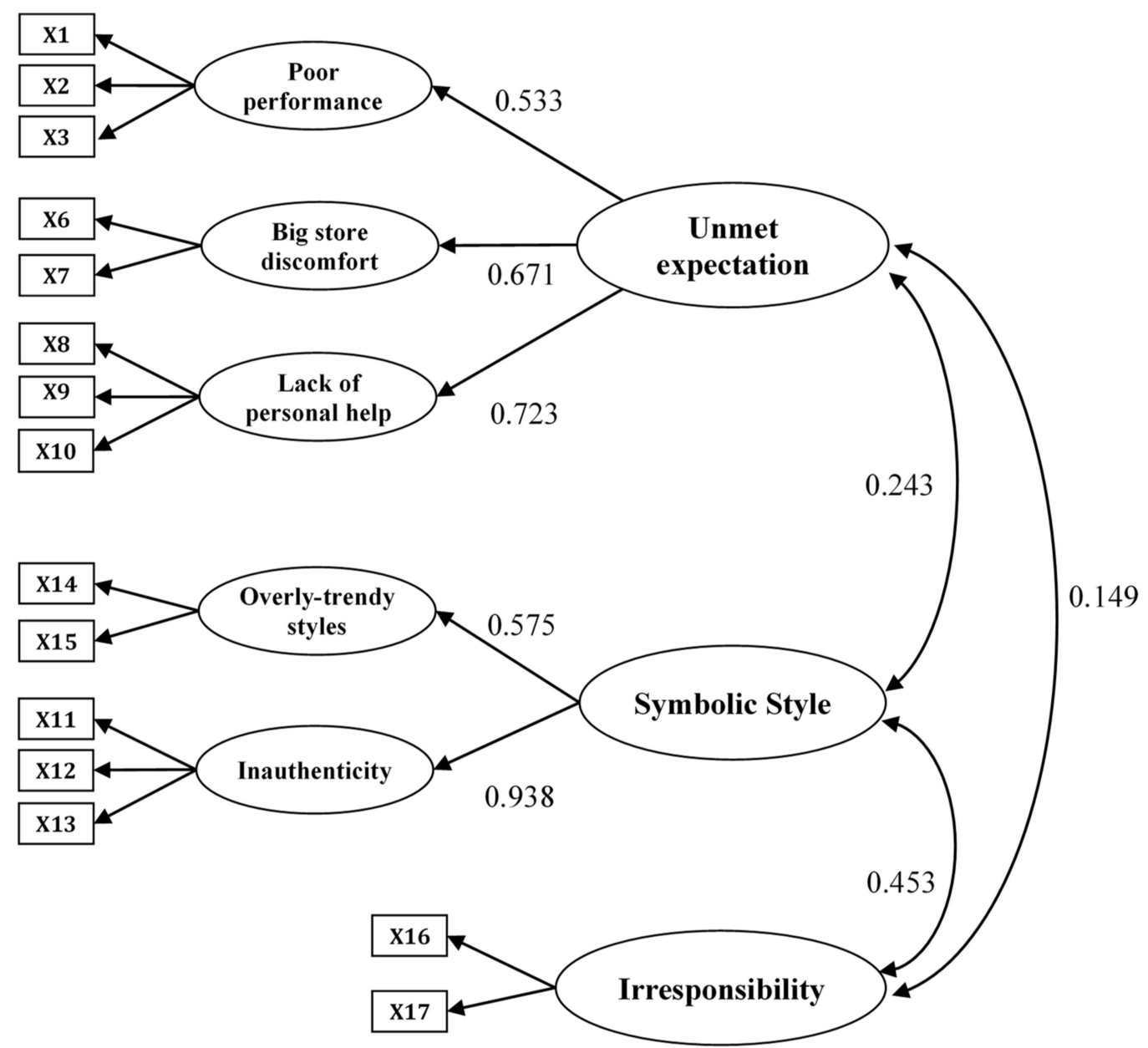

Figure 2. Spain: second-order confirmatory factor analysis. Notes: $\chi^{2}=165.288, d f=96, p=0.000$, normed $\chi^{2}=1.722$, GFI $=0.913, \mathrm{CFI}=0.948$, RMSEA $=0.060$. All the estimates are statistically significant at $p<0.05$.

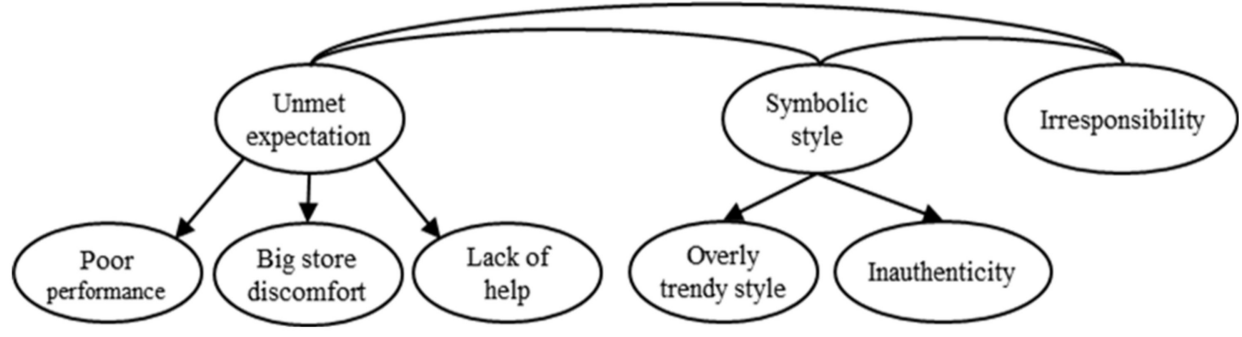

Figure 3. Proposed model.

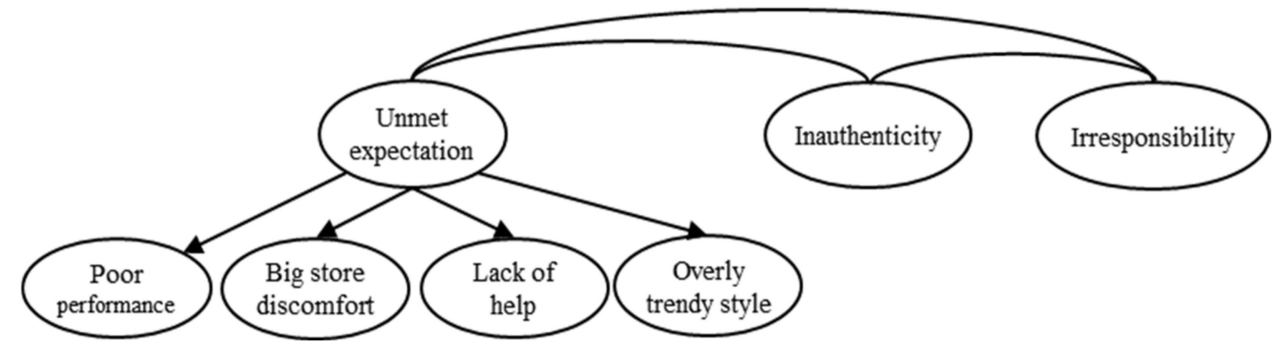

Figure 4. Competing model. 
Table 2. Competing model comparison.

\begin{tabular}{cccccccc}
\hline & $\chi^{\mathbf{2}}$ & $d f$ & Normed $\chi^{\mathbf{2}}$ & $\boldsymbol{\Delta} \chi^{2} / d f$ & GFI & CFI & RMSEA \\
\hline Proposed model & 165.288 & 96 & 1.722 & & 0.913 & 0.948 & 0.060 \\
Competing model & 187.815 & 97 & 1.936 & $22.527(p<0.001)$ & 0.899 & 0.932 & 0.068 \\
\hline
\end{tabular}

The result of the measurement model test (Table 3) indicates that the specified model fit was satisfactory in Korea $\left(\chi^{2}=203.231, d f=124, p=0.000\right.$, normed $\chi^{2}=1.639$, GFI $=0.923$, CFI $=0.961$, RMSEA $=0.054)$. All the standard factor loadings of the first-order factors were significant at $p<0.01$. The Cronbach's alpha values of all the constructs exceeded 0.70 . The average variance extracted (AVE) for the eight constructs ranged from 0.503 to 0.779 , and the composite reliability $(\mathrm{CR})$ was from 0.509 to 0.849 .

In Spain $\left(\chi^{2}=165.288, d f=96, p=0.000\right.$, normed $\chi^{2}=1.722$, GFI $=0.913$, CFI $=0.948$, RMSEA $=0.060$ ), the factor loadings of the measurement model were all above 0.7 and significant at $p<0.01$. The Cronbach's alpha values for the constructs were all above 0.70, The AVEs for the six constructs were above 0.05 , and the CR ranged from 0.600 to 0.744 . The values for AVE and the squared correlation of constructs were compared with each pair of constructs to examine the discriminant validity. In Korea and Spain, all the squared correlations were lower than the corresponding AVEs. Thus, the discriminant validity of the constructs was satisfactory.

Table 3. Measurement model of fast fashion avoidance beliefs.

\begin{tabular}{|c|c|c|c|c|}
\hline \multirow{2}{*}{ Constructs and Items } & \multicolumn{2}{|c|}{ Korea } & \multicolumn{2}{|c|}{ Spain } \\
\hline & $\begin{array}{c}\text { Standard } \\
\text { Factor Loading } \\
(\lambda)\end{array}$ & $\begin{array}{c}\text { Chronbach's } \alpha \\
\text { AVE } \\
\text { CR }\end{array}$ & $\begin{array}{c}\text { Standard } \\
\text { Factor Loading } \\
(\lambda)\end{array}$ & $\begin{array}{c}\text { Chronbach's } \alpha \\
\text { AVE } \\
\text { CR }\end{array}$ \\
\hline \multicolumn{5}{|l|}{ Poor performance } \\
\hline $\mathrm{X} 1$ Stitching is not strong enough & 0.751 & 0.870 & 0.787 & 0.841 \\
\hline $\mathrm{X} 2$ Product quality is not good enough & 0.936 & 0.703 & 0.815 & 0.641 \\
\hline $\mathrm{X} 3$ Cheap material is used & 0.817 & 0.853 & 0.799 & 0.744 \\
\hline Overly trendy styles & & 0.751 & & 0.834 \\
\hline X4 Styles are too trendy to use for a long time & 0.899 & 0.629 & 0.893 & 0.721 \\
\hline X5 Styles are too sensitive to the changing trends & 0.670 & 0.662 & 0.803 & 0.740 \\
\hline Big store discomfort & & 0.670 & & 0.720 \\
\hline X6 Clothing displays are not well organized & 0.722 & 0.503 & 0.750 & 0.602 \\
\hline \multicolumn{5}{|l|}{ Lack of personal help } \\
\hline X8 It is hard to get help from salespeople & 0.880 & 0.830 & 0.855 & 0.861 \\
\hline X9 Salespeople at stores are rude & 0.764 & 0.630 & 0.861 & 0.679 \\
\hline \multicolumn{4}{|l|}{ Inauthenticity } & 0.734 \\
\hline X11 Styles are similar to other brands & 0.673 & 0.833 & 0.839 & 0.808 \\
\hline X12 Styles have too much mass appeal & 0.864 & 0.631 & 0.724 & 0.591 \\
\hline X13 Styles are dull & 0.832 & 0.849 & 0.739 & 0.717 \\
\hline Deindividuation & & 0.869 & & - \\
\hline X14 Fast fashion makes it hard to express my personality & 0.929 & 0.779 & - & \\
\hline \multicolumn{4}{|l|}{ Irresponsibility } & \\
\hline X16 Fast fashion contaminates the environment & 0.870 & 0.806 & 0.724 & 0.780 \\
\hline X17 Fast fashion exploits labor in & 0.771 & 0.676 & 0.769 & 0.542 \\
\hline less developed countries & - & 0.709 & 0.715 & 0.666 \\
\hline \multicolumn{5}{|l|}{ X18 Fast fashion stimulates over-consumption } \\
\hline Foreignness & & 0.860 & & - \\
\hline X19 Fast fashion ruins my fashion & 0.923 & 0.761 & - & \\
\hline X20 Fast fashion perverts traditional culture & 0.819 & 0.831 & - & \\
\hline
\end{tabular}

Notes: All $\lambda$ were statistically significant at $p<0.001$. Korea: $\chi^{2}=203.231, d f=124, p=0.000$, normed $\chi^{2}=1.639$, $\mathrm{GFI}=0.923, \mathrm{CFI}=0.961, \mathrm{RMSEA}=0.054$. Spain: $\chi^{2}=141.415, d f=89, p=0.000$, normed $\chi^{2}=1.589, \mathrm{GFI}=0.914$, $\mathrm{CFI}=0.963, \mathrm{RMSEA}=0.054$.

The results show that fast fashion avoidance beliefs are formed differently in the two countries. Korean consumers have unmet expectations, symbolic incongruence, and ideological incompatibility of fast fashion avoidance beliefs as referred to in previous studies [25,61]. In Spain, deindividuation and foreignness are excluded from fast fashion avoidance beliefs. Unmet expectations, symbolic style, 
and irresponsibility dimensions are formed as higher-order avoidance beliefs. These three dimensions are also supported by Lee et al. [61], who argued that brand avoidance was evoked by experiential, symbolic, and moral motivations.

\subsection{Effects of Fast Fashion Avoidance Beliefs on Anti-Fast Fashion Consumption}

Anti-Fast fashion consumption was estimated by three items. A Cronbach's alpha of 0.929 indicated satisfactory internal consistency for the construct. A multiple regression analysis was conducted to test the effects of fast fashion avoidance beliefs on anti-consumption by countries (Table 4). The R-square values of multiple regressions were 0.399 in Korea and 0.089 in Spain. The explanatory power of fast fashion avoidance beliefs on anti-fast fashion consumption was relatively lower in Spain than in Korea because of the exclusion of foreignness and deindividuation.

Table 4. The effects of fast fashion avoidance beliefs on anti-fast fashion consumption.

\begin{tabular}{ccc}
\hline Independents Variables & $\begin{array}{c}\text { Korea } \\
(\boldsymbol{n}=\mathbf{2 2 4})\end{array}$ & $\begin{array}{c}\text { Spain } \\
(\boldsymbol{n}=\mathbf{2 0 3})\end{array}$ \\
\hline Poor performance & 0.095 & $0.198^{*}$ \\
Overly trendy styles & 0.071 & $-0.174^{*}$ \\
Big store discomfort & 0.068 & 0.016 \\
Lack of personal help & 0.085 & 0.033 \\
Inauthenticity & -0.042 & -0.071 \\
Deindividuation & $0.245^{* *}$ & - \\
Irresponsibility & -0.134 & $0.187^{*}$ \\
Foreignness & $0.424^{* * *}$ & - \\
\hline$R^{2}$ & 0.399 & 0.089 \\
F-value & $17.827^{* * *}$ & $3.192^{* *}$ \\
\hline Notes: ${ }^{* * *} p<0.001 ;{ }^{* *} p<0.01 *^{*} p<0.05$. &
\end{tabular}

Consequently, deindividuation $(\beta=0.245, p<0.01)$ and foreignness $(\beta=0.424, p<0.001)$ had significant effects on anti-consumption intention in Korea. These factors are influential sub-dimensions of fast fashion avoidance beliefs only in Korea and lead to avoiding intention. Consumers in Korea avoid fast fashion when they perceive the foreignness of fast fashion and deindividuation.

In Spain, poor performance $(\beta=0.198, p<0.05)$ and irresponsibility $(\beta=0.187, p<0.05)$ have significantly positive effects on avoidance behavior. Consumers in Spain have more experience with fast fashion as compared with consumers in Korea's fast fashion market. The experiences of consumers in Spain enable them to evaluate product attributes substantially and form negative beliefs towards fast fashion performance. Irresponsibility is also a crucial factor leading to the avoidance of fast fashion in Spain. However, overly trendy style has a negative effect on the intention to avoid fast fashion $(\beta=-0.174, p<0.05)$.

The results show differences of effects among fast fashion avoidance beliefs, which lead to fast fashion anti-consumption behavioral intention. In Korea, negative beliefs about ideological and symbolic aspects of fast fashion consumption are crucial to anti-consumption. We observe a difference with Spain. In Spain, beliefs about the more intrinsic features of fast fashion, such as poor performance and ethical issues such as irresponsibility, have effects on anti-consumption. Interestingly, beliefs about overly trendy styles have a negative effect on anti-consumption behavioral intention. Hence, for consumers in Spain, the overly trendy style of fast fashion is not perceived as a negative but rather as a positive factor that decreases anti-consumption intention with fast fashion brands. As suggested in previous studies [72,73] with knowledge-based evaluation, Spanish consumers have relatively higher levels of expertise and tend to consider experiential information when evaluating fast fashion. 


\section{Conclusions}

\subsection{General Discussion}

The present study aims to understand consumer's fast fashion avoidance from the perspective of the sustainable consumption movement. Although the study has limitations in terms of generalizing the results due to convenience sampling in Korea and Spain, we investigated the conceptual structures of fast fashion avoidance beliefs that influence the anti-consumption of fast fashion to diagnose the current stage and suggest the future of fast fashion. Previous studies on anti-fast fashion have focused on the effect of sustainable consumption, such as attitudes toward sustainable fashion $[4,40,60]$, ethical concerns $[20,56]$, and attitudes toward fast fashion [23,24], on purchasing fast fashion. The current study expanded the understanding of anti-fast fashion behavior to determine avoidance beliefs as drivers to evoke avoidance behavior by adopting the framework of fast fashion avoidance. People favoring sustainable movement or ethical consumption does not mean that they avoid fast fashion consumption. In other words, consumers' anti-fast fashion behavior should be distinguished from behavior associated with sustainability, indicating this study highlights potential strategies that marketers could implement to address brand avoidance.

Spanish consumers are found to form a different structure of identity and morality in their fast fashion avoidance beliefs compared to Korean consumers. Kim et al. [25] indicated that symbolic incongruence consists of inauthenticity and deindividuation as sub-dimensions of negative beliefs. However, the study in Spain found that overly trendy style is reflected in the symbolic style with inauthenticity, and that irresponsibility is formed independently as a dimension of moral avoidance belief. Cavender and Lee [70] studied the US consumers' fast fashion avoidance and suggested that foreignness was not a sub-dimension of avoidance beliefs, but that localism as the orientation of slow consumption can influence fast fashion avoidance beliefs. The findings imply that negative beliefs about fast fashion are due to the evaluation of the fast fashion brand's products and services as well as the invasion of individual identity in the process of fashion diffusion. In Spain, inauthenticity $($ mean $=4.957)$ and overly trendy style (mean $=4.867)$, which are in symbolic style as identity dimensions of avoidance beliefs, have higher values than the other constructs, as shown in Table 5 . Generally, consumers in Spain are likely to perceive a high level of identity invasion by fast fashion, and the negative belief of symbolic congruence is identified to avoid fast fashion.

In terms of the effect of fast fashion avoidance beliefs on the anti-consumption of fast fashion, deindividuation and foreignness have positive effects on the anti-consumption of fast fashion in Korea. Meanwhile, unmet expectations and irresponsibility positively affect avoidance behavior in Spain. Interestingly, overly trendy style has a negative effect on the anti-consumption of fast fashion. This result corresponds to the expressive aspect of apparel, such as design, which does not cause dissatisfaction but satisfaction. Although fast fashion focuses on limited time use and disposal due to the speedy supply of trendy products [74], consumers in Spain may consider fast fashion styles to be a normative standard, based on many previous studies that focused on the positive aspects of fast fashion $[36,75,76]$. Thus, the overly trendy style of fast fashion weakens the anti-consumption of fast fashion in Spain. Fast fashion plays a leading role in domestic fashion consumption because Spain can be regarded as an origin country where fast fashion brands such as ZARA and MANGO were first launched. 
Table 5. Construct mean of fast fashion avoidance beliefs.

\begin{tabular}{ccc}
\hline & $\begin{array}{c}\text { Korea } \\
(n=\mathbf{2 2 4})\end{array}$ & $\begin{array}{c}\text { Spain } \\
(n=\mathbf{2 0 3})\end{array}$ \\
\hline Poor performance & 4.019 & 4.228 \\
Overly trendy styles & 4.133 & 4.867 \\
Big store discomfort & 3.544 & 4.359 \\
Lack of personal help & 3.620 & 4.024 \\
Inauthenticity & 4.041 & 4.957 \\
Deindividuation & 3.515 & - \\
Irresponsibility & 3.818 & 4.661 \\
Foreignness & 3.037 & - \\
\hline
\end{tabular}

These different patterns of results in Korea and Spain can be explained in two ways. First, even though the fast fashion industry has been well established in both countries, their status in the growth cycle is quite different. According to the industry growth model [77,78], an industry in the growth phase of profitability begins as products gradually attract the attention of a mass market. In comparison, in the maturity stage, the majority of the companies in the industry are already well-established and the industry has already reached its saturation point. Products at this stage become more common and popular among the general public because their customers' demands are generally high and consistent. The fast fashion market in Korea can be regarded as a less mature market as compared to Spain, and therefore the different stages of the growth cycle in these countries can influence consumers' fast fashion avoidance beliefs.

Second, consumers in Spain and Korea are likely to have different levels of fast fashion knowledge and familiarity based on their accumulated experiences in their respective markets. Previous studies have explained that the level of consumers' domain-specific knowledge can lead to different decision-making processes [79,80]. More specifically, in Korea, where fast fashion retail is in a less matured stage (vs. Spain), perceptual issues, such as foreignness and deindividuation, rather than product relevant information, influence consumer behavioral intention of fast fashion anti-consumption. Given that Korean consumers lack sufficient experience in fast fashion as compared with Spanish consumers, thei awareness of social issues, such as the spread of fast fashion in society and industrial infringement, is linked perceptually to their negative beliefs about fast fashion, thereby triggering anti-consumption sentiments. Similarly, Karaosman et al. [81] examined the relationship between consumer behavior and ethical fashion by focusing on fast fashion retail through Spanish consumers. They found that Spanish consumers are not likely to link ethics to the fast fashion industry. Furthermore, the ethical communication of fashion brands is not considered transparent, indicating that Spanish consumers are sensitive to social and environmental issues related to fast fashion. In original fast fashion markets, such as Spain, consumers do not perceive foreignness as a negative belief of fast fashion, which means that fast fashion ruins domestic fashion and traditional culture. Hence, foreignness is important only to Korean consumers when deciding to avoid fast fashion. Spanish consumers also have had substantially diverse experiences of fast fashion brands for a long time. Although fast fashion provides trendy products promptly $[1,31]$, the low quality of products and the notion of disposable fashion are considered as negative aspects $[25,74]$. Given their accumulated experiences in fast fashion, Spanish consumers can build the criteria with which to decide whether they consume or avoid fast fashion, specifically in terms of product-relevant information. Prior-built schema on fast fashion in Spanish consumers may be associated with a negative belief, specifically unmet expectations.

\subsection{Theoretical and Managerial Implications}

The findings of this empirical study provide several contributions to the existing literature on sustainable consumption in the apparel area. First, this study enriches anti-consumption research by identifying consumers' fast fashion avoidance behavior. This study challenges the work of previous studies that were conducted as conceptual papers or exploratory studies. The results of the current 
study can be helpful in understanding consumers' anti-consumption associated with the apparel usage process because the data from both Korea and Spain are collected and analyzed empirically.

Second, through the findings of the study, we can clarify consumers' behaviors associated with sustainable fast fashion consumption, which is a highly contested concept [30]. Young consumers prefer fast fashion because of its cheap price and trendy style while simultaneously supporting the sustainable movement in the fashion industry. However, this study revealed that young consumers in Korea and Spain indicated their intention to avoid fast fashion consumption in terms of unmet expectations, symbolic incongruence, and ideological incompatibility. In particular, Spanish consumers who have diverse experiences with fast fashion brands for a long time hesitate to consume fast fashion because of social or environmental concerns, such as the irresponsibility aspect, whereas the physical aspects of fast fashion, such as the overly trendy style, did not matter at all to Spain consumers. Based on this result, we can understand consumers' anti-fast fashion consumption, which is a distinct concept from sustainable consumption. Thus, the argument of previous studies (i.e., young consumers are taking contradictory steps in fast fashion consumption) should start by distinguishing between the terms anti-consumption and sustainable consumption.

Third, this study reconfirms the conceptual structure and sub-dimensions of fast fashion avoidance beliefs. Kim et al. [25] suggested and confirmed the conceptual structure of fast fashion avoidance beliefs and we reconfirmed and showed its satisfactory validity and reliability in Korea and Spain. Cavender and Lee [70] also identified fast fashion avoidance beliefs based on Kim et al.'s structure [25] in the US. This study's findings also revealed that the conceptual structure and its sub-dimensions of fast fashion avoidance beliefs can differ based on the growth stage of fast fashion and consumers' accumulated experience. In the mature stage of fast fashion in particular, the construct of avoidance beliefs must be retested to ensure the validity of the high-ordered structure. Nevertheless, this study is also limited in terms of generalizing the results to consumers avoiding fast fashion because the data collected came from young consumers only. Hence, future research may expand the study to include various consumers with diverse fast fashion experiences.

In comparing consumers' fast fashion experiences, further studies are required to test the formation of avoidance beliefs and predict the behavior of sustainable fashion consumption. Previous studies $[4,23,24]$ referred the gap between attitudes and behaviors of fast fashion. Kim et al. [25] suggested the moderating effects of the lack of alternatives between the beliefs and behaviors of fast fashion avoidance. Considering that a difference in consumer experiences according to the fast fashion retailing stage exists, confirming whether anti-fast fashion behavior is induced by the consumers' characteristics and fast fashion-buying behaviors is important.

In terms of managerial implications, fast fashion retailers can adapt our findings in formulating a strategy for corporate social responsibility (CSR). CSR has become an important factor that can trigger anti-action when the demand is not met. For fast fashion brands, social responsibility is required to strengthen future marketing strategies. These strategies can be established based on consumers' negative fast fashion beliefs. For example, because fast fashion brands have been key players for a long time in the domestic fashion industry, Spanish consumers are more sensitive to fast fashion retailers' irresponsibility as environmental and ethical concerns, rather than products' physical aspects as a social concern associated with the intellectual property issue. In contrast, Korean consumers, who are less knowledgeable and experienced, will focus on whether fast fashion ruin individuals' personalities (i.e., deindividuation) or cultural base authenticity (i.e., foreignness). In this regard, fast fashion retailers in the mature market can attract consumers by promoting their ethical and sustainable concerns and attempts (e.g., slogans for "we love the environment" or "we care for our employees in the developing countries"). Fast fashion retailers in a less mature or growing market can appeal to their generality, which is not harmful to individuals" personalities or cultural aspects (e.g., slogans for "we are one globally" or "we are the same"). These distinct CSR strategies can help fast fashion retailers to turn back consumers' anti-consumption behavior and prepare for a bright future under social and ethical consumption movements. 
Author Contributions: Conceptualization, N.Y., H.K.L., and H.J.C.; Methodology, N.Y.; Data Collection, N.Y. and H.J.C.; Analysis, N.Y.; Writing, N.Y., H.K.L., and H.J.C. All authors have read and agreed to the published version of the manuscript.

Funding: This research received no external funding.

Conflicts of Interest: The authors declare no conflict of interest.

\section{References}

1. Joy, A.; Sherry, J.F., Jr.; Venkatesh, A.; Wang, J.; Chan, R. Fast fashion, sustainability, and the ethical appeal of luxury brands. Fash. Theory 2012, 16, 273-295. [CrossRef]

2. Loeb, W. Zara Leads in Fast Fashion. Forbes. Available online: http://www.forbes.com/sites/walterloeb/2015/ 03/30/zara-leads-in-fast-fashion/\#4dee76361d79/ (accessed on 2 August 2020).

3. Hendriksz, V. Boohoo, ASOS and Missguided Pave the Way for 'Ultrafast Fashion'. Available online: https: //fashionunited.uk/news/fashion/boohoo-asos-missguided-pave-the-way-for-ultrafast-fashion/2017052424625/ (accessed on 2 August 2020).

4. Blazquez Cano, M.; Henninger, C.E.; Alexander, B.; Franquesa, C. Consumers' knowledge and intentions towards sustainability: A Spanish fashion perspective. Fash. Pract. 2020, 12, 34-54. [CrossRef]

5. Fletcher, K. Sustainable Fashion E Textiles: Design Journeys; Earthscan Publications Ltd.: Oxford, UK, 2008.

6. Schrank, A. Ready-to-wear development? Foreign investment, technology transfer, and learning by watching in the apparel trade. Soc. Forces 2004, 83, 123-156. [CrossRef]

7. Kozinets, R.V.; Handelman, J.M. Adversaries of consumption: Consumer movements, activism, and ideology. J. Consum. Res. 2004, 31, 691-704. [CrossRef]

8. Johansson, E. Slow Fashion: The Answer for a Sustainable Fashion Industry? Master's Thesis, The Swedish School of Textiles, Borås, Sweden, 2010.

9. Niinimäki, K.; Hassi, L. Emerging design strategies in sustainable production and consumption of textiles and clothing. J. Clean. Prod. 2011, 19, 1876-1883. [CrossRef]

10. Rheannon, F. The Lesson of Rana Plaza for CSR: Worker Empowerment the Key to Safety? Available online: https:/www.csrwire.com/blog/posts/854-the-lesson-of-rana-plaza-for-csr-worker-empowermentthe-key-to-safety (accessed on 10 December 2019).

11. The Guardian. Clothing Corporations Need to Step Up for Bangladesh Factory Collapse Victims. Available online: https://www.theguardian.com/commentisfree/2013/sep/18/bangladesh-factory-victims-corporations (accessed on 10 December 2019).

12. Fashion Revolution. Available online: https://www.fashionrevolution.org/about/ (accessed on 30 July 2020).

13. Mintel. $56 \%$ of Americans Stop Buying from Brands They Believe Are Unethical. Available online: https://www.mintel.com/press-centre/social-and-lifestyle/56-of-americans-stop-buying-from-brands-theybelieve-are-unethical (accessed on 7 November 2019).

14. Lee, M.S.; Seifert, M.; Cherrier, H. Anti-consumption and governance in the global fashion industry: Transparency is key. In Governing Corporate Social Responsibility in the Apparel Industry after Rana Plaza; Palgrave Macmillan: New York, NY, USA, 2017; pp. 147-174.

15. McNeill, L.; Moore, R. Sustainable fashion consumption and the fast fashion conundrum: Fashionable consumers and attitudes to sustainability in clothing choice. Int. J. Consum. Stud. 2018, 39, $212-222$. [CrossRef]

16. Shaw, D.; Riach, K. Embracing ethical fields: Constructing consumption in the margins. Eur. J. Mark. 2011, 45, 1051-1067. [CrossRef]

17. Business Human Rights Resource Centre. The Rana Plaza Building Collapse in Bangladesh. Available online: http://business-humanrights.org/en/the-rana-plaza-building-collapse-in-bangladesh-one-year-on (accessed on 20 November 2019).

18. Dewan, N. From Zara to H\&M, Fast Fashion Faces the Age of Reckoning. Available online: https://economictimes.indiatimes.com/small-biz/sme-sector/from-zara-to-hm-fast-fashion-face-theage-ofreckoning/articleshow/72120398.cms (accessed on 30 July 2020).

19. Masunaga, S. Does Fast Fashion Have to Die for the Environment to Live? Available online: https: //www.latimes.com/business/story/2019-11-03/fast-fashion-sustainable (accessed on 1 August 2020). 
20. Stringer, T.; Mortimer, G.; Payne, A.R. Do ethical concerns and personal values influence the purchase intention of fast-fashion clothing? J. Fash. Mark. Manag. 2020, 24, 99-120. [CrossRef]

21. Blasi, S.; Brigato, L.; Sedita, S.R. Eco-friendliness and fashion perceptual attributes of fashion brands: An analysis of consumers' perceptions based on twitter data mining. J. Clean. Prod. 2020, 244, 118701. [CrossRef]

22. Noh, M.; Johnson, K.K.P. Effect of apparel brands' sustainability efforts on consumers' brand loyalty. J. Glob. Fash. Mark. 2019, 10,1-17. [CrossRef]

23. Marques, A.D.; Marques, A.; Ferreira, F. Homo Sustentabilis: Circular economy and new business models in fashion industry. SN Appl. Sci. 2020, 2, 306. [CrossRef]

24. Diddi, S.; Yan, R.N.; Bloodhart, B.; Bajtelsmit, V.; McShane, K. Exploring young adult consumers' sustainable clothing consumption intention-behavior gap: A Behavioral Reasoning Theory perspective. Sustain. Prod. Consum. 2019, 18, 200-209. [CrossRef]

25. Kim, H.; Choo, H.J.; Yoon, N. The motivational drivers of fast fashion avoidance. J. Fash. Mark. Manag. 2013, 17, 243-260. [CrossRef]

26. Statista. Leading European Fast Fashion Brands Based on Total Revenue Worldwide in 2019. Available online: https://www.statista.com/statistics/1094176/european-fast-fashion-brands-ranked-by-revenue/ (accessed on 1 August 2020).

27. Statista. Consumer Market Outlook. Available online: https://www.statista.com/outlook/90050100/153/ apparel/spain (accessed on 17 August 2018).

28. Fashionnetkorea. Available online: https://www.fashionnetkorea.com/market/market_gl_kfashion.asp (accessed on 18 August 2018).

29. Odom, W.; Zimmerman, J.; Forlizzi, J.; López Higuera, A.; Marchitto, M.; Cañas, J.; Lim, Y.K.; Nam, T.J.; Lee, M.H.; Lee, Y.; et al. Fragmentation and transition: Understanding perceptions of virtual possessions among young adults in Spain, South Korea and the United States. In Proceedings of the SIGCHI Conference on Human Factors in Computing Systems, Paris, France, 27 April-2 May 2013; pp. 1833-1842.

30. Bly, S.; Gwozdz, W.; Reisch, L.A. Exit from the high street: An exploratory study of sustainable fashion consumption pioneers. Int. J. Consum. Stud. 2015, 39, 125-135. [CrossRef]

31. Hines, T.; Bruce, M. Fashion Marketing; Routledge: Oxford, UK, 2007.

32. Choi, T.M.; Liu, N.; Liu, S.C.; Mak, J.; To, Y.T. Fast fashion brand extensions: An empirical study of consumer preferences. J. Brand Manag. 2010, 17, 472-487. [CrossRef]

33. Sull, D.; Turconi, S. Fast fashion lessons. Bus. Strategy Rev. 2008, 19, 4-11. [CrossRef]

34. Barnes, L.; Lea-Greenwood, G. Fast fashion in the retail store environment. Int. J. Retail Distrib. Manag. 2010, 38, 760-772. [CrossRef]

35. Christopher, M.; Lowson, R.; Peck, H. Creating agile supply chains in the fashion industry. Int. J. Retail Distrib. Manag. 2004, 32, 367-376. [CrossRef]

36. Cachon, G.P.; Swinney, R. The value of fast fashion: Quick response, enhanced design, and strategic consumer behaviour. Manag. Sci. 2011, 57, 778-795. [CrossRef]

37. De Jorge Moreno, J.; Carrasco, O.R. Efficiency, internationalization and market positioning in textiles fast fashion. Int. J. Retail Distrib. Manag. 2016, 44, 397-425. [CrossRef]

38. Martinez Barreiro, A. Towards a new system for the fashion industry-The Zara model. Rev. Int. De Sociol. 2008, 66, 105-122. [CrossRef]

39. Childs, M.L.; Jin, B. Is Uppsala model valid to fashion retailers? An analysis from internalisation patterns of fast fashion retailers. J. Fash. Mark. Manag. 2014, 18, 36-51.

40. Kim, Y.; Oh, K.W. Which Consumer Associations Can Build a Sustainable Fashion Brand Image? Evidence from Fast Fashion Brands. Sustainability 2020, 12, 1703. [CrossRef]

41. Fletcher, K. Slow fashion: An invitation for systems change. Fash. Pract. 2010, 2, 259-265. [CrossRef]

42. Ledezma, V. Globalization and Fashion: Too Fast, Too Furious. Laurier Undergrad. J. Arts 2017, 4, 9.

43. Chatzidakis, A.; Lee, M.S. Anti-consumption as the study of reasons against. J. Macromark. 2013, 33, $190-203$. [CrossRef]

44. Bick, R.; Halsey, E.; Ekenga, C.C. The global environmental injustice of fast fashion. Environ. Health 2018, 17, 92-96. [CrossRef] 
45. Akhter, S.; Rutherford, S.; Chu, C. Sewing shirts with injured fingers and tears: Exploring the experience of female garment workers health problems in Bangladesh. BMC Int. Health Hum. Rights 2019, 19, 1-9. [CrossRef]

46. Khan, S.; Malik, A. Environmental and Health Effects of Textile Industry Wastewater in Environmental Deterioration and Human Health; Springer: Dordrecht, The Netherlands, 2014; pp. 55-71.

47. Anguelov, N. The Dirty Side of the Garment Industry: Fast Fashion and Its Negative Impact on the Environment and Society; CRC Press Taylor \& Francis Group: Boca Raton, FL, USA, 2016.

48. Byun, S.E.; Sternquist, B. The antecedents of in-store hoarding: Measurement and application in the fast fashion retail environment. Int. Rev. Retail Distrib. Consum. Res. 2008, 18, 133-147. [CrossRef]

49. Doeringer, P.; Crean, S. Can fast fashion save the US apparel industry? Socio-Econ. Rev. 2006, 4, 353-377. [CrossRef]

50. Reinach, S. China and Italy: Fast fashion versus prêt a porter. Towards a new culture of fashion. Fash. Theory 2005, 9, 43-56.

51. Lee, M. Fashion Victim: Our Love-Hate Relationship with Dressing, Shopping and the Cost of Style; Broadway: New York, NY, USA, 2003.

52. Moisander, J.; Pesonen, S. Narratives of sustainable ways of living: Constructing the self and the other as a green consumer. Manag. Decis. 2002, 40, 329-342. [CrossRef]

53. Pookulangara, S.; Shephard, A. Slow fashion movement: Understanding consumer perceptions-An exploratory study. J. Retail. Consum. Serv. 2013, 20, 200-206. [CrossRef]

54. Shim, S.; Kim, J.; Na, Y. An exploratory study on up-cycling as the sustainable clothing life at home. Fash. Textiles 2018, 5-20. [CrossRef]

55. Jägel, T.; Keeling, K.; Reppel, A.; Gruber, T. Individual values and motivational complexities in ethical clothing consumption: A means-end approach. J. Mark. Manag. 2012, 28, 373-396. [CrossRef]

56. Gam, H. Are Fashion Conscious Consumers More Likely to Adopt Eco-Friendly Clothing? J. Fash. Mark. Manag. 2011, 15, 178-193.

57. Diddi, S.; Yan, R.N. Consumer Perceptions Related to Clothing Repair and Community Mending Events: A Circular Economy Perspective. Sustainability 2019, 11. [CrossRef]

58. Gam, H.J.; Cao, H.; Farr, C.; Heine, L. C2CAD: A sustainable apparel design and production model. Int. J. Cloth. Sci. Technol. 2009, 21, 166-179. [CrossRef]

59. Pookulangara, S.; Shephard, A.; Mestres, J. University community's perception of sweatshops: A mixed method data collection. Int. J. Consum. Stud. 2011, 35, 476-483. [CrossRef]

60. Danziger, P.N. 6 Global Consumer Trends for 2019, and the Brands That Are Out in Front of Them. Available online: https://www.forbes.com/sites/pamdanziger/2019/01/13/6-global-consumer-trends-andbrands-thatare-out-in-front-of-them-in-2019/\#70dba444fe4c (accessed on 2 August 2020).

61. Lee, M.; Motion, J.; Conroy, D. Anti-consumption and brand avoidance. J. Bus. Res. 2009, 62, 169-180. [CrossRef]

62. Oliva, T.A.; Oliver, R.L.; MacMillan, I.C. A catastrophe model for developing service satisfaction strategies. J. Mark. 1992, 56, 83-95. [CrossRef]

63. Thompson, C.J.; Arsel, Z. The Starbucks brandscape and consumers' (anticorporate) experiences of glocalization. J. Consum. Res. 2004, 31, 631-642. [CrossRef]

64. Rindell, A.; Strandvik, T.; Wilén, K. Ethical consumers' brand avoidance. J. Prod. Brand Manag. 2014, 23, 114-120. [CrossRef]

65. Cherrier, H. Anti-consumption discourses and consumer-resistant identities. J. Bus. Res. 2009, 62, $181-190$. [CrossRef]

66. Craig-Lees, M. Anti-consumption: Concept clarification and changing consumption behavior. In Proceedings of the Anti-Consumption Seminar, International Centre for Anti-Consumption Research, Auckland, New Zealand, 20-21 June 2006.

67. Iyer, R.; Muncy, J.A. Purpose and object of anti-consumption. J. Bus. Res. 2009, 62, 160-168. [CrossRef]

68. Lee, M.S.; Conroy, D.; Motion, J. Brand avoidance: A negative promises perspective. In NA-Advances in Consumer Research; McGill, A.L., Shavitt, S., Eds.; Association for Consumer Research: Duluth, MN, USA, 2009; Volume 36, pp. 421-429.

69. Knittel, Z.; Beurer, K.; Berndt, A. Brand avoidance among Generation Y consumers. Qual. Mark. Res. Int. J. 2016, 19, 27-43. [CrossRef] 
70. Cavender, R.C.; Lee, M.Y. Exploring the Influence of Sustainability Knowledge and Orientation to Slow Consumption on Fashion Leaders' Drivers of Fast Fashion Avoidance. Am. J. Theor. Appl. Bus. 2018, 4, 90-101. [CrossRef]

71. Kim, E.H. New marketing strategies for fast fashion brands in South Korea: An exploration of consumer's purchasing experiences. Fash. Text. Res. J. 2018, 20, 629-644. [CrossRef]

72. Johnson, E.J.; Russo, J.E. Product familiarity and learning new information. J. Consum. Res. 1984, 11, 542-550. [CrossRef]

73. Gardner, M.P. Advertising effects on attributes recalled and criteria used for brand evaluations. J. Consum. Res. 1983, 10, 310-318. [CrossRef]

74. Cline, E. Where does Discarded Clothing Go? Available online: https://www.theatlantic.com/business/ archive/2014/07/where-does-discarded-clothing-go/374613/ (accessed on 29 August 2019).

75. Bhardwaj, V.; Fairhurst, A. Fast fashion: Response to changes in the fashion industry. Int. Rev. Retail Distrib. Consum. Res. 2010, 20, 165-173. [CrossRef]

76. Doyle, S.A.; Moore, C.M.; Morgan, L. Supplier management in fast moving fashion retailing. J. Fash. Mark. Manag. 2006, 10, 272-281. [CrossRef]

77. Porter, M.E. Competitive Strategy: Techniques for Analyzing Industries and Competitors; The Free Press: New York, NY, USA, 2008.

78. Scott, M.; Bruce, R. Five stages of growth in small business. Long Range Plan. 1987, 20, 45-52. [CrossRef]

79. Taylor, S.E.; Fiske, S.T. Salience, attention, and attribution: Top of the head phenomena. Adv. Exp. Soc. Psychol. 1978, 11, 249-288.

80. Beattie, A.E. Effects of product knowledge on comparison, memory, evaluation, and choice: A model of expertise in consumer decision-making. Adv. Consum. Res. 1982, 9, 336-341.

81. Karaosman, H.; Alonso, G.M.; Grijalvo, M.; Brun, A. The impact of ethical fashion on Spanish consumers. Dir. Organ. 2015, 57, 63-73.

(C) 2020 by the authors. Licensee MDPI, Basel, Switzerland. This article is an open access article distributed under the terms and conditions of the Creative Commons Attribution (CC BY) license (http://creativecommons.org/licenses/by/4.0/). 